\title{
Water in the Study of Southeast Asia
}

\author{
LEONARD Y. ANDAYA \\ Department of History, University of Hawai'i at Manoa, 2500 Campus Rd, \\ Honolulu, Hawai'i 96822, USA \\ andaya@hawaii.edu
}

Published online: 20 December 2018

To cite this article: Andaya, L.Y. 2018. Water in the study of Southeast Asia. KEMANUSIAAN the Asian Journal of Humanities 25(Supp. 1): 21-38, https://doi.org/10.21315/kajh2018.25.s1.2

To link to this article: https://doi.org/10.21315/kajh2018.25.s1.2

\begin{abstract}
This paper advocates the use of a water perspective in the study of Southeast Asia. Such a perspective, it is argued, is multidimensional and complex, and incorporates an understanding of the physical characteristics of water, the transformations it undergoes through human intervention, and the sociocultural meaning that is applied to it by individual human communities. Moreover, water is a generic term that refers to a variety of types (salt, fresh, brackish, land-water) and forms (oceans, seas, straits, estuaries, rivers, lakes, ponds, reservoirs, canals). By citing examples across the world, this paper proposes the study of the differing combinations of types and forms of water in order to gain a greater precision of its role in Southeast Asia. At the heart of the water approach is the understanding that a body water should be studied as an equal partner to the human community. By examining the dynamic interaction of these two elements, important connectivities and new spatialisations based on water could greatly enhance our understanding of society. The seas, oceans, the littoral, and other forms and types of water are all understudied and deserve renewed attention if we are to find new ways of thinking and learning about Southeast Asia's past, present and even its future.
\end{abstract}

Keywords and phrases: ecology, historical spaces, rivers, Southeast Asia, water perspective

\section{Introduction}

More than 70 percent of Southeast Asia is water, and the monsoon rains are a regular feature of the region, and yet few have attempted to focus on water as an essential element - not just a setting - for understanding Southeast Asian society. This paper is an attempt to gauge the possibilities of using a water perspective in the study of this region, relying heavily on certain ideas of scholars who have been pioneers in such studies in different parts of the world. The paper will begin with a theoretical discussion of a "water system" and its three important aspects, and then 
proceed to examine the various types of water that can form the basis of a study. In the discussion, I have emphasised those features that could be profitably examined in Southeast Asia, though the comments have general relevance for other parts of the world.

\section{Theoretical Ideas on Water}

Terje Tvedt, a leading scholar of water, identifies three layers in a water system (Tvedt 2010a, 147, 157-159, 161). The first consists of the physical form of water and of its behaviour in relation to the human group. This involves learning the nature of water (the patterns of precipitation, rates of evaporation, etc.) and its environment. To take the study of a river, for example, the rate of flow of the water changes depending on the width of the river, the volume of water it contains at different times due to seasonal change and rates of sedimentation, the form of the river, and the effect of other water features on the river, such as lakes or tributaries. This particular physical water landscape determines the constraints and the prospects of productive activity of a community.

The second layer is the modifications or management of the physical water unit by the human community. The building of dams or weirs, canals, reservoirs, ponds and other water holes may affect the physical aspects of the river and hence the riverine culture of the community. Through such human interventions, the technology and managerial skills of a community can be known. It also reveals what particular options were chosen and why, thus helping to gain a better understanding of the social and environmental priorities of the community. One of the most impressive examples of such water management in Southeast Asia is in Angkor. In order to address the natural phenomenon of floods during the rainy season and lack of water in the dry season, the Angkorians built a complex water system of village tanks fed by rainfall and ground water, extensive reservoirs (baray), and canals linked to rivers and the Tonle Sap (Great Lake). Through this water technology, Angkor was able to expand northward from the Tonle Sap into marginal lands that suffered from water scarcity in the dry season. ${ }^{1}$

The third layer is the cultural attitudes towards water, which affect the relationship between water and the community. For example, among the tribal Manang community in Nepal, explanations for interment of the dead in the spring, summer and fall, and cremation in the winter are structured in a spiritual manner but based on a pragmatic consideration. It is possible to inter bodies when the ground has not yet been frozen solid. The cultural explanation is that burial would not pollute the air with burning flesh and thus anger the gods, who could then withhold much needed rains. In the winter, however, the opposite effect is desired so that cremation 
is practiced to anger the gods and make them stop sending more snow (Oestigaard $2005,154)$. Water management practices may therefore be explained in religious or supernatural terms. The same body of water may be perceived in radically different ways by neighbouring communities based on their varying experiences with that particular source of water and the divergent traditions transmitted by their ancestors. There is no single nor unchanging "traditional" view of water, but a shifting perspective that accommodates changes in hydrological and social circumstances. Such changes can occur quickly and last for only a short time. A diachronic study can therefore be revealing of this dynamic relationship between a water resource and a human community.

Water can be divided into fresh water, salt water, brackish water and "water" that incorporates both land and water. Units of fresh water would include rivers, lakes, ponds, reservoirs, canals and even glaciers. Salt water may be conceived as oceans, seas and straits, with distinctions made between the coastal waters and the open sea, with the latter divided into a pelagic or upper layer and the demersal or deeper layer extending down to the ocean floor. Brackish water is usually found at the confluence of bodies of fresh and salt water at estuaries, along coastal mangroves, and in wetlands. Finally, there is a continuum of land and water found mainly in Oceania incorporating the mountains or hills, the river valleys, the coast, the reefs and the lagoons. ${ }^{2}$ This combined perception of land and water can also be applied to societies such as the Cham in Central Vietnam, where their former polities or kingdoms were precisely delineated as consisting of an interior watershed in the mountains, an intervening river valley, and the coast where the river reaches the sea (Li 1998, 18-19).

Attitudes towards the different types of water are worth noting. Fresh water is usually associated with life, fertility and benign gods, who are greatly revered by societies dependent on the soil for a livelihood. Salt water, on the other hand, is often viewed with fear and danger and with capricious and at times malevolent gods. In some societies, fresh water and salt water are viewed as complementary, while brackish water occupies a special place representing the union of fresh and salt water. In Southeast Asia, beings or places that "cross" the defined spheres of existence are believed to be spiritually potent (Calo 2009, 113-114, 124; Capistrano-Baker 1994, 24), hence the association of brackish water areas as sites of potential power. Among Oceanic societies, including ancient Hawai'i, an Austronesian society that had similar cultural roots as the societies in island Southeast Asia, land and water form a single social and environmental entity in a continuum from the mountains and the source of a river, to the valleys and plains through which the river flows, to the coast, and out to the intertidal zone (and in some Oceanic islands, to lagoons). ${ }^{3}$ Minor gods associated with the constituent 
parts are controlled by a few major gods, thus spiritually preserving the unity. In Hawai'i, the powerful god Kane had two aspects: god of the ocean (Kane-huli$k o a$ ) and god of fresh water (Kane-wai-o). The former was regarded as masculine, active and external, while the latter was feminine, passive and internal (Malo 1971, 83; Water Resource Research Center 2006).

These are some of the theoretical and general considerations that should inform any attempt to use water as an academic approach. The following sections are elaborations on these general ideas in order to demonstrate the possibilities of doing research using a water perspective.

\section{Rivers and Other Fresh Water Sources}

It is necessary to determine which type of fresh water one is examining, whether rivers, tributaries, springs, reservoirs, ponds or irrigation channels. Of these fresh water sources, rivers have been the most studied because river basins with their fertile soils and effective drainage systems have historically been sites for the largest population concentrations (de Blij 2005, 97). Expansion of settlements occurred along major rivers, where goods and ideas arriving by sea moved from the coast and spread throughout the length of the river and far into the interior (Higham 1996, 323). While the role of rivers as the pathway for cultural exchange has been well-recognised, other aspects of the river are usually left unexplored. This thus presents an opportunity to re-examine the river in a different way that may provide a new understanding of the past.

As in the study of oceans, rivers are often not problematised even though they too are socially constructed and not unchanging neutral bodies of water. There is often an unreflective acceptance among the social sciences and humanities of the idea that the river is a single entity along its entire course. Biologists and ecologists, however, clearly view a river as consisting of three distinctive parts: the headwaters, the mid-reaches and the lower reaches; each distinguished by the change of the physical environment, such as the width of the river, character of the water flow and its relationship to its bank. ${ }^{4}$ It is also important to examine the natural changes that have occurred over time, as has been ably shown in a series of studies of the Red River in Vietnam (Li 2016; 2006a, 125-139; 2006b, 147-162). The natural course of a river may be diverted naturally through silting, but it could also be altered because of its perceived social and economic value to the human community. Diversion of the river could spell the doom of a once prosperous city located on its banks and the emergence of a village into a new thriving settlement. 
By viewing water together with its adjacent land as an interrelated unit, one would discover that the river is indeed perceived as being segmented, and that people living along its banks have given a stretch of the river a specific name which they themselves have adopted as an ethnonym. This is the case in Borneo and appears to have been the case in Mindanao as well (Pringle 1970; Paredes 2016). Attitudes towards the river may thus differ from one group to another depending upon the section of the river that is associated with the group. The varying physical aspects of the river may determine the local people's belief of the kind of water spirit that inhabits that space. In early Laos, for example, the Mekong River and its many tributaries were all associated with a different sacred snake or naga, thus highlighting the different domains (Mayoury and Nagaosrivathana 2007, 22). Human attitudes depend upon a group's immediate experience with a stretch of the river, and so cultural attitudes may differ significantly even among neighbouring communities sharing the same river.

Mainland Southeast Asia has a number of long rivers that rise in the mountains in China and flow out to the South China Sea after a long journey through the various states. In addition there are numerous tributaries of these primary rivers that crisscross the mainland. Island Southeast Asia has fewer major rivers, mostly concentrated on Sumatra and Borneo, but there are many smaller rivers that made these areas in the past truly "paddle cultures", where boat travel was the only feasible form of communication. One approach to rivers that Southeast Asian scholars have used is to identify the important divisions between upstream and downstream. By acknowledging the differences and the complementarity of these two major components of the river, they have been able to make useful statements about their relative strengths and shifting relationships according to historical circumstances (Andaya 1993; Kathirithamby-Wells 1993). In Southeast Asia, scholars have usually regarded downstream polities as being more favourably located to gain the material and cultural benefits of maritime trade. Yet there are examples in Burma (Myanmar), Vietnam, Cambodia, and even island Southeast Asia where the upstream polities have long dominated the relationship. It is therefore important to provide not only a synchronic but also a diachronic study of a river to assess the relationship of its upstream and downstream components.

Extremely long rivers like the Mekong in mainland Southeast Asia and the Kapuas in southwest Borneo may be understood in more complex ways than simply in the upstream-downstream dichotomy. Let us take the Kapuas River as an example. The Kapuas River has been the home of many different indigenous Dayak and Malay communities, and until the mid-20th century they were organised according to the demands of their natural environment. The river consisted of the headlands in 
the interior mountains, the interior lakes, the "upriver" segments, the "downriver" segments and the coast. Bennet Bronson's dendritic model based on Sumatra's river systems is useful (Bronson 1977), but it needs to be modified by the situation in each individual river. In the Kapuas River, there are additional elements that complicate the model. Communities in the headlands of the Kapuas were not isolated nor dependent upon the river for their survival or prosperity. They were free to move using paths, some very steep and treacherous, through the mountain interior to other headlands and attach themselves to communities outside the Kapuas River. The lakes formed yet another ecological division, with fishing communities operating very much like other lake-dwelling populations elsewhere in Southeast Asia. Then there were the various upstream communities that dotted the interior, mainly along tributaries of the Kapuas. Their linkages were formed primarily with the particular settlement located at the confluence of the tributary and the Kapuas, as is suggested in Bronson's model. Unlike in Sumatra, however, communities linked by a single tributary tended to operate as one, enabling the settlement at the confluence to become a minor kingdom. These independent, individual upriver kingdoms had mutually beneficial trade arrangements with a principal downriver port kingdom, ruled by a royal family that originated from abroad and settled by a largely migrant population (Andaya, forthcoming). To study the Kapuas River, the upstream-downstream relationship requires modifications to account for the significant variations along the course of the main river.

Another important consideration in studying rivers or other fresh water sources is the effects of interventions from international, national or local bodies. In the case of the Mekong River, which originates in China and flows through the countries of Myanmar, Laos, Thailand, Cambodia and Vietnam, the upstream-downstream communities may differ considerably because of such interventions. The decision by China to build a dam at the upper reaches of the river has important consequences for downriver settlements and countries. In addition, different national goals may affect one bank of the river and not another, as in the Mekong which forms a natural boundary between Laos and Thailand. Within countries themselves, there could be conflicting views regarding the development of the river. In the case of Laos, there is the ongoing struggle between business people and environmentalists as to the best way to use the river and its low-lying banks that are inundated during the monsoon rains but become good arable land during the dry season. Rivers or parts of rivers can thus be sites of contestation.

While rivers may be the most studied fresh water source, others such as man-built canals, reservoirs and ponds can be studied individually or as a system. Canals may link one waterway to another, or help to divert water from the main river or tributary for irrigation purposes, but each society creates ways in which such 
diversion can be maintained to benefit all. It is no coincidence that ancient irrigation schemes have direct links to temples, a feature that is well-documented in Angkor and Bali. In Bali's subak system of irrigation, water from the highest and thus most sacred source in Lake Batur in the mountains, is blessed by the high priest of the "temple of the crater lake" as it flows down to the numerous downstream shrines in individual fields. There is no need for government intervention, as the sacred waters continue through local temples and hence provide a spiritual sanction for the delicate balancing of water allocation for the individual fields and collective efforts to control pests (Lansing 1991). Rulers in Bali and ancient Java promoted the building of holy places with water, supported by funds from tax revenues to assure their maintenance in perpetuity. It was believed that dead rulers occupied these special places, and water formed the link between the world of the living and the dead, "between the immortality of the spirit and the fertility of the soil" (Christie 1992, 22). The presence of a temple or a sacred site is a visual reminder of the protective power of the local deity and its supernatural sanction against any infringement of water usage agreements sworn under oath. Such spiritual sanctions have proved to be effective in enforcing water management schemes (Mosse 2011, 226). In late 20th century Java, local initiatives employing spiritual sanctions operated in tandem with state measures based on scientific findings to assure the successful flow of water from its source to downriver villages (Duewel 2014, 6, 7, 46).

Reservoirs are used for irrigation, to conserve water for the dry season, to drain the land during the wet season, or for religious purposes. Individual ponds built by one family may serve as a source of water and irrigation for home gardens. Different uses made of each water unit may influence the manner in which it is conceptualised by members of that community. Reservoirs and ponds are generally viewed as placid and beneficial. In Angkor, the large impressive reservoirs or barays are now widely believed to have been built for the needs of the population during the dry season and for religious purposes, ${ }^{5}$ and "evoked oceans surrounding Mount Meru in traditional Indic cosmology" (Stark and Acabado 2014, 15). If the barays are symbolic oceans, then the purification that occurs at these sites can perhaps be likened to the purification associated with the ocean. This is made explicit in the variant Javanese and Malay versions of the story of Bima discussed below under the section on salt water.

In India, the Rig Veda cites Apah, the Waters, as the first residence of Nara, the Eternal Being, and so water is regarded as pratishtha, "the underlying principle and the foundation of the universe" (Joshi and Fawcett 2006, 121). The sacred Mt. Meru is associated with the heavenly lake Anavatapta, the source of the elixir (amrta) of immortality and the waters of the Ganges River (Pham 2015, 
32-33). All seven of the large rivers in India, but most especially the Ganges, constitute the sacred geography, within which temples, holy tanks and places of worship in riverbeds are found (Tvedt 2010b, 40). In a Javanese version of this Hindu myth, the amrta contains the essence of plant sap, which contains potent curative properties (Sbeghen 2004, 131-134, 154). In Balinese macrocosmic ideas, kaja means mountain-wards and hence "higher", while kelod is seawards and "lower", with similar metaphysical connotations as in the West (Lansing 1974, 57-58). Upstream water is therefore regarded as nourishing, possessing life-giving properties, while downstream is associated with water that cleanses pollution. A farmer will build a small shrine on the plot of land regarded as sacred because it is where the irrigation water flows from upstream into the rice field (Lansing 1991, 54-55). Modern European view, on the other hand, is a pragmatic, business one in which the profit motive overrides all other considerations. Rivers in Europe are regarded as a form of natural capital that could be harnessed for productive purposes, such as the taxing of barge traffic. Amount levied required consideration of the nature of the river at various times, how often goods had to be loaded and unloaded at various parts of the river, the seasonal variations in the availability of river transport, and the volume of cargo that could be carried by the various types of river transport (Tvedt 2010b, 33).

Equally important in discussions of fresh water sources is ownership. In lands where there are limited supplies of fresh water, the diversion of water could substantially alter the nature of the community. A striking case is from Hawai' $i$, where American-owned plantations in the late 19th and 20th centuries obtained rights to divert river and underground water from their natural channels to the plantation fields. This diversion disrupted precious water from the kalo (taro) patches that produced poi, the staple food of the people. Not only was a major food source undermined, bringing hardships to the community, but the fate of the kalo plant itself, regarded as the ancestor of the Hawai' ians, came to symbolise the demise of a people and their way of life (Castle and Murakami 1991, 149-151).

\section{Salt Water Bodies: Oceans, Seas and Straits}

The oceans and seas have long fascinated the Western public, particularly stories of shipwrecks, pirates and adventures among fabled people inhabiting oceans at the ends of the world. The "South Seas", the Caribbean and the various Asian seas have for centuries elicited great interest and encouraged authors to spin tales in an attempt to satisfy a seemingly insatiable public appetite for exotic South Seas and other maritime adventures. The "seas" in these types of writings simply formed a backdrop for fantastic tales that served to confirm popular knowledge of the "Marvels of the East". Only in the last few decades has the study of oceans 
and seas become a proper source of academic research, spurred on by increased interest in the environment and in global connections. The growing number of studies of oceans and seas has spawned noteworthy efforts to delineate "seas" or "zones" as proper research objectives. There are now sufficient theoretical debates on the seas to inform discussions on salt water bodies. The debate has become so precise that the 2007 volume edited by Jerry Bentley, entitled Seascapes: Maritime Histories, Littoral Cultures, and Transoceanic Exchanges (Bentley, Bridenthal and Wigen 2007) was criticised for not distinguishing between oceans and seas. The seas provide the local variations within an ocean, thus contributing to a more complex picture of the connectivities within this space. The result of this attention to the differences between oceans and seas is a more nuanced examination of the functioning of these bodies of salt water that can serve as models for innovative frameworks and more subtle interpretations of all forms of water.

Until recently the primary research focus has been on oceans: first the Atlantic (which has been viewed from various perspectives, such as the "Black Atlantic" or the "Latin Atlantic"), then subsequently the Pacific and the Indian Oceans. Specific journals have arisen to cater to the increasing interest in the various aspects of communities living along the continental shores of these oceans (and far less on those living "on" the oceans). The major exception to this ocean-centric approach is the Mediterranean "Sea", which is the most studied body of water in the world and which has set a model for all other investigations of oceans and seas. The South China Sea, which has been used for centuries as the major maritime trade route to and from China, is now receiving far greater attention for its disputed waters which contain vast reserves of oil and natural gas. The claimants - China, Brunei, Indonesia, Malaysia, the Philippines, Taiwan and Vietnam - have begun to stake claims using (and misusing) evidence from the past.

Philip E. Steinberg has examined how ocean space in the past was conceptualised and used by different societies. He contends that oceans and seas were socially constructed following three different models with three different emphases: (1) the Mediterranean model based on imperial Rome's view of the sea as a space that can be subject to a state's social influence but not owned by any individual state; (2) the Micronesian-style model, where the ocean is treated like the land, where cultural signs and attitudes towards usufruct of the ocean are the equivalent of those on land; and (3) the Indian Ocean model, which constructs the ocean as a special trading space insulated from the power struggles of land-based societies, and where the ocean is primarily a transport surface (Steinberg 2003, 44ff). The geographer Martin Lewis has argued, however, that to focus on oceans is unproductive, and that it is better to identify "oceanic arcs", i.e., points along the ocean which are meaningfully connected (Lewis 1999, 204). 
International trade has always been a major way of creating meaningful connections. By determining what constitutes the major focus of an exchange, one can plot out the various routes and communities that form the necessary nodes in the network. One can then proceed to examine the role of each community, and the cultural reception and ideological impact of such an object. Some nodes in the connection are merely transitional ports, with perhaps only one or a few of the communities interested in the object or objects being traded. Other parts of the connection may be involved in order to obtain other objects, and so a number of different objects may circulate in the same network but with specific objects having a special meaning to specific communities. When Peregrine Horden and Nicholas Purcell wrote their highly regarded work on the Mediterranean, they described their study as "the human history of the Mediterranean Sea and its coastlands" (Horden and Purcell 2009, 9). In contrasting their work to that of Fernand Braudel's magisterial opus on the Mediterranean (Braudel 1987), they argue that studies should be of communities interacting within (hence being "of" the ocean) and not just coincidentally located in ("in" the ocean) that body of water. Their detailed and sophisticated examination of the Mediterranean and its littoral continually places the human element to the fore, but the significance comes in the manner in which people interact with the various aspects of the environment. It is a model that focuses attention on the continual and shifting interaction between the human and physical environment of the sea and its coasts.

As in fresh water, there is an intermediate point between the ocean and the seas, which is the "strait", a narrow waterway that links one ocean or sea to another. One of the most famous is the Straits of Melaka, which connects the Indian Ocean to the South China Sea and has continued to be one of the busiest and most important waterways in the world. Until at least the middle of the second millennium CE, the Straits of Melaka was the only known body of water that linked the major civilisations to the east and west of Southeast Asia. While neither an ocean nor a sea, the strait exhibits characteristics that combine features of both. It is more likely than in seas of oceans for a state to exercise stewardship over or even direct control of a strait. When a strait connects oceans, as has been the case with the Straits of Melaka, then it becomes the nodal point for interlocking global networks.

Salt water in some societies have a cleansing and purifying function as is made explicit in the variant Malay tellings of the story of Bima, one of the Pandawa brothers in the Indian epic, the Mahabharata. In the Malay version of the Javanese Dewa Ruci (also known as Nawarucci and Bima Suci), Bima goes in search of kawitra water (air kawitra) to cleanse his body of pollution. Only two places contain that special water: a pond at the foot of the sacred Hindu Mt. Mahameru, and in the middle of the sea (di pusat tasik) (Arps 2018, 70-71). Ancient Hawai' 'ians 
viewed salt water as the ultimate source of purifying power. They mixed salt water with turmeric or red earth and sprinkled the mixture onto a site or an individual in order to cleanse them of impurities. The process of training dancers for the sacred hula was fraught with spiritual dangers, and so those who were entrusted with building the structure dedicated to the training of hula dancers were forbidden to use improper language, have sex or eat certain food. If such infractions occurred, the offending person was immediately sprinkled with the salt water and turmeric mixture. Students entering into the structure to learn the hula had to be sprinkled with this water before entering the sacred ground. At the conclusion of training and before the admittance of the participants into the guild of hula dancers, they took a plunge in the ocean totally naked in order to cleanse them from all impurities. Finally, the kumu or "priest" or head of the school (halau) bathed in the ocean to complete the process of purification at the end of the training (Emerson 1909, $14-15,29,31)$.

\section{Water in the "In-between" Spaces}

Among many societies, including those of Southeast Asia, the ability to move across spheres or planes is regarded as a feat of supernatural significance. The reason is that the area in between two planes is regarded as a liminal space with spiritual potency. In the view of the anthropologist-philosopher Greg Dening, it is these "crossings" between heaven and earth (rainbows), between land and sea (canoes), and land and sky (feathers) that are favourite symbols employed by Pacific islanders (Dening 2006, 15). A similar observation can be made of Southeast Asia, where such creatures as frogs, crocodiles, birds (and the associated feathered headdresses of humans) occupy this liminal "in-between" space and hence have an important cultural role in society. The presence of these in-between images on the mantles of the ancient Dong Son drums identifies the drums as repositories of spiritual powers and legitimises their function in confirming political power of leaders of the community and in assuring the fertility and prosperity of the group (Calò 2009, 84; L.Y. Andaya 2016).

In the study of water, it is brackish water that occupies this in-between space between fresh and salt water. Fresh and salt water meet and mingle at estuaries to form a brackish water environment, where special flora and fauna thrive. Estuaries (Mal. Kuala) are themselves in-between sites and thus associated with spiritual potency. The Helong people of West Timor have a legend that ascribes their origins to the island of Seram. When they left Seram and reached the northern coast of Timor, one of the brothers turned into a crocodile and led the group to the estuary of the Koinino River, where they founded a kingdom (Hägerdal 2012, 95). It is also worth noting that the crocodile is itself regarded as special because of its ability to live both on land and sea. 
The brackish environment of the estuaries, the mangrove swamps and the interior wetlands are exploited fully by the sea people (Orang Laut and Sama Bajau) and the forest people (Orang Asli), two groups who themselves occupy an in-between space in society. Among the Sama Bajau of eastern Indonesia, the place of great value is the sago palm swamp (gonggang), for it is trunk of the palm which is processed to obtain the sago that forms their staple diet (Lowe 2003, 127). The sea peoples in the past lived much of their lives on the sea in boats but took temporary shelter on land during dangerous monsoon weather. A similar crossing of spheres is attributed to the Orang Asli, who live partly in the forest in the realm of animals, and partly at the forest edge in the land of people. For these reasons, both the sea peoples and forest peoples are believed to possess extraordinary spiritual powers.

The liminality of the brackish environment is also captured in folklore, where in Mandar traditions in South Sulawesi the wife of Nabi Khidir walks the area along the coastline, where sea meets land, serving as a guardian at the division of these two worlds. In this local tradition she is entrusted with maintaining watch at the borders of land and sea in the transition zone on the coast (B.W. Andaya 2016, 254). ${ }^{6}$ The implication is that there is need to preserve the land from the dangers from the ocean, which is precisely the attitude of the Lumad towards the Dumagat ("sea people") (Paredes 2016, 334-337).

Another in-between space that has come to be studied with increasing frequency is the littoral. The term itself specifically refers to the shoreline and shoreline communities, but the culture of the coast is far more complex. There is a difference between communities that are "littoral" and oriented to the sea, and those coastal communities whose inhabitants look inward to the land and are farmers and only occasionally fishermen (Pearson 1985, 1-8). In Timor, the coastal dwellers shun the sea and rely on neighbouring islands to provide both boats and navigation, as well as goods from the outside world. By contrast, there are communities that occasionally till the land or forage on shore, but whose primary preoccupation is the sea. It is these seaward-looking communities that constitute the true littoral communities, where the land is a secondary consideration to the seaward orientation. In island Southeast Asia, there is a Malay-Indonesian term for the littoral, which is pasisir. It incorporates not simply a living space but a way of life, and in Indonesia it is often associated with the port cities that looked outward to the sea, participated in trade, and were the entry points of foreign goods and ideas, including foreign religions.

Littoral communities have even been described as "amphibious", moving between land and sea with connections extended in both directions. Geographers have used the terms "foreland" to refer to a littoral community and its principal port's relations 
to other littoral communities around a common ocean or even around the globe; and umland for the immediate environment of the port and its community. This littoral community is separated culturally from the "hinterland", which is landbased and orientated to the interior (Pearson 2006, 353-354; Pearson 2003, 31). Littoral communities are an example of connectivity, not attached to the land nor even to a linking sea, but to a world-wide network of culturally similar societies. In the ideological sense of in-between places, the littoral is a powerful mediator of influences and goods between the outside world and the world of the interior.

\section{The Land-Water Continuum}

This last category of "water" has characterised societies living on small islands or isolated coasts where the ocean or the sea is the dominant feature. While it is the communities in the Pacific Ocean that have constructed this perception of water, similar examples can be found in the seas of eastern Indonesia. In a land-water continuum, the mountains, plains, streams, beaches, reefs and lagoons form the "land" unit. But it is the sea portion of the continuum that is most significant. It contains the pathways that crisscross the surface of the ocean connecting the islanders to their relatives and friends in other places, as well as to specific areas of the sea where food and trade products are gathered. Their world is a web of pathways identified by rocks, reefs and other signs on a well-traversed ocean (Steinberg 2003, 55). The connectivities spanning the entire length and breadth of the Pacific is a reason that Epeli Hau'ofa has rejected the view that people in the Pacific are isolated on tiny islands in a vast, forbidding ocean. Instead, he emphasises the connections of the islands to other places on the ocean and beyond to whatever lands and seas settled by the Pacific diaspora. He prefers to speak of this sea of islands as "Oceania" to emphasise the connectivity and the dynamism of this unified Pacific Ocean world (Hau'ofa 1994, 155-157).

The cultural beliefs of these societies reflect the successful adaptation to their landwater continuum. In keeping with their unified view of land and water, their gods and heroes move seamlessly through the different spheres of the skies, the land and the seas (Hau'ofa 1994, 155-157). In the case of Hawai'i, as mentioned above, the powerful god Kane contained two aspects: as the god of the sea and as the god of fresh water. The histories of societies from the land-water continuum reflect the transcending of worlds, as gods, humans and other creatures inhabiting the various spheres interact together since the time of the origins of the group (Hau'ofa 1994). In recent times, the culture of communities from a land-water continuum has reemerged as a legitimate rendering of the past, effectively countering the dominant historical narratives that are products of Western colonisation of indigenous knowledge. Vilsoni Hereniko, for example, argues that traditional forms of 
knowledge on his home island of Rotuma, such as fictional stories called te hanuju (a type of gossip of the ancestors), as well as song and dance, etc., are legitimate and important historical sources. Yet these types of texts have been neglected by Western and Western-trained local historians who regard them as "unreliable" (Hereniko 2000, 78-81). Studies such as Hereniko's are models that could be profitably applied in Southeast Asia, where similar environmental conditions exist as in Oceania.

\section{Conclusion}

The objective of this paper is to introduce the idea of water as an approach to the study of Southeast Asia. A water perspective is multidimensional and complex, and incorporates an understanding of the physical characteristics of water, the transformations it undergoes through human intervention, and the sociocultural meaning that is applied to it by individual human communities. Moreover, water is a generic term that refers to a variety of types (salt, fresh, brackish, land-water) and forms (oceans, seas, straits, estuaries, rivers, lakes, ponds, reservoirs, canals). Each of these types and forms can be studied in different combinations in order to acquire greater precision. At the heart of the water approach is the understanding that a body water should be studied as an equal partner to the human community. By examining the dynamic interaction of these two elements, one can gain a greater understanding of the connectivities and new spatialisations that are created. The seas, oceans, the littoral, and other forms and types of water are all understudied and deserve renewed attention if we are to find new ways of thinking and learning about Southeast Asia's past, present and even its future.

\section{Notes}

1. There is a fairly substantial literature on Angkor. Sydney University is undertaking a 15-year study called the Greater Angkor Project, which is under the direction of Professor Roland Fletcher of the archaeology department. Using laser imaging, they have been mapping the city of Angkor with its intricate water works. For an excellent study of the effect of environmental change on the water system, which may have caused Angkor's demise, see Penny (2010).

2. Steinberg refers to this form of "sea" as a Micronesian model (Steinberg 2003, 5257). But this is a conception that is shared among other Oceanic societies (Hviding 1996; D’Arcy 2006).

3. The intertidal zone refers to the slope of the island and the reefs that are permanently covered by sea water, but when exposed could at times be even more extensive than the island. It is a zone of rich plant and animal life and hence an important economic resource for its inhabitants (Ammarell 1999, 25, 28-29).

4. This is known as the River Continuum Concept and may have been first discussed in Vannote et al. (1980, 130-137). 
5. The building of such large reservoirs would have required large amounts of labour and expense, hence demonstrating the great powers and beneficence of the ruler. The barays may not have been used for irrigation but for supplying water for the use of the large population in the Angkor area during the dry season when water became scarce. Philip Taylor has shown that, among the Khmer community living in Vietnam's Camau Peninsula, only the wealthiest could build ponds large enough to supply a family in the long dry season. Others were forced to work cooperatively to build communal ponds for the use of everyone. The massive size of the barays would have been understood by the people as symbols of the incomparable powers of the Angkorian ruler (Taylor 2014, 114-117).

6. Nabi Khidir is regarded as a mystical figure with variant Islamic and non-Islamic traditions, and so the use of "Nabi" (prophet) reflects one such tradition. It is interesting that it is his wife, and not Nabi Khidir himself, who is the subject of the Mandar tale.

\section{References}

Ammarell, G. 1999. Bugis navigation (Monograph 48). New Haven: Yale Southeast Asian Studies.

Andaya, B.W. 1993. Cash cropping and upstream-downstream tensions: The case of Jambi in the seventeenth and eighteenth centuries. In Southeast Asia in the early modern era: Trade, power, and belief, ed. A. Reid, 91-122. Ithaca: Cornell University Press.

2016. Rivers, oceans and spirits: Water cosmologies, gender, and religious change in Southeast Asia. TRaNS (Trans-Regional and National Studies of Southeast Asia) 4(2): 239-263. https://doi.org/10.1017/trn.2016.2

Andaya, L.Y. 2016. The social value of elephant tusks and bronze drums among certain societies in eastern Indonesia. Bijdragen tot de Taal-, Land-en Volkenkunde 172(1): 66-89. https://doi.org/10.1163/22134379-17201001

Forthcoming. World of the southern Malays. In Performing Malay in a small island world: Otodidak artists and the politics of identity in Indonesia's Riau archipelago, ed. M. Kartomi. Copenhagen: NIAS Press.

Arps, B. 2018. Dronas betrayal and Bima's brutality: Javanaiserie in Malay culture. In Traces of the Ramayana and Mahabharata in Javanese and Malay literature, eds. Ding Choo Ming and W. van der Molen, 58-98. Singapore: ISEAS-Yusof Ishak Institute.

Bentley, J.R., Bridenthal, R. and Wigen, K. 2007. Seascapes: Maritime histories, littoral cultures, and transoceanic exchanges. Honolulu: University of Hawai'i Press.

Braudel, F. 1987. The Mediterranean and the Mediterranean world in the age of Philip II (vol. 2). London: Fontana Press.

Bronson, B. 1977. Exchange at the upstream and downstream ends: Notes toward a functional model of the coastal state in Southeast Asia. In Economic exchange and social interaction in Southeast Asia: Perspectives from prehistory, history, and ethnography, ed. K. Hutterer, 39-52. Ann Arbor: University of Michigan, Centre for South and Southeast Asian Studies. 
Calò, A. 2009. The distribution of bronze drums in early Southeast Asia: Trade routes and cultural spheres. British Archaeological Reports (BAR) International Series 1913, Oxford: Archaeopress.

Capistrano-Baker, F.H. 1994. Art of island Southeast Asia: The Fred and Rita Richman collection in the Metropolitan Museum of Art. New York: Metropolitan Museum of Art.

Castle, J. and Murakami, A. 1991. Water rights. In Native Hawaiian rights handbook, ed. M.K. MacKenzie, 149-172. Honolulu: Native Hawaiian Legal Corporation.

Christie, J.W. 1992. Water from the ancestors: Irrigation in early Java and Bali. In The gift of water: Water management, cosmology and the state in South East Asia, ed. J. Rigg, 7-25. London: SOAS.

D'arcy, P. 2006. The people of the sea: Environment, identity, and history in Oceania. Honolulu: University of Hawai'i Press.

De Blij, H. 2005. Why geography matters; Three challenges facing America: Climate change, the rise of China, and global terrorism. Oxford: Oxford University Press.

Dening, G. 2006. Deep times, deep spaces: Civilizing the sea. In Sea changes: Historicizing the ocean, eds. B. Klein and G. Mackenthun, 13-35. New York and London: Routledge.

Duewel, J. 2014. Changing agricultural technologies and socio-cultural ecologies: Lowland and upland irrigation management along a watershed in Central Java, Indonesia. Paper presented at Conference on Water, Sogang University, Seoul, 26-27 June.

Emerson, N.B. 1909. Unwritten literature of Hawaii: Sacred songs of the hula. Bulletin 38 of the Bureau of American Ethnology. Washington: Government Printing Press.

Geertz, H. 1963. Indonesian cultures and communities. In Indonesia, ed. R. McVey, 2496. New Haven: HRAF Press.

Hägerdal, H. 2012. Lords of the land, lords of the sea: Conflict and adaptation in early colonial Timor, 1600-1800. Leiden: Brill. https://doi.org/10.1163/9789004253506

Hau'ofa, E. 1994. Our sea of islands. The Contemporary Pacific: A Journal of Island Affairs 6(1): 148-161.

Hereniko, V. 2000. Indigenous knowledge and academic imperialism. In Remembrance of Pacific pasts, ed. R. Borofsky, 78-91. Honolulu: University of Hawai'i Press.

Higham, C. 1996. The bronze age of Southeast Asia. Cambridge: Cambridge University Press.

Horden, P. and Purcell, N. 2009. The corrupting sea: A study of Mediterranean history. London: Blackwell.

Hviding, E. 1996. Guardians of Marovo lagoon: Practice, place, and politics in maritime Melanesia. Honolulu: University of Hawai'i Press.

Joshi, D. and Fawcett, B. 2006. Water, Hindu mythology and an unequal social order in India. In A history of water, vol. 3: The world of water, eds. T. Tvedt and T. Oestigaard, 119-136. London: I.B. Tauris.

Kathirithamby-Wells, J. 1993. Hulu-hilir unity and conflict: Malay statecraft in east Sumatra before the mid-nineteenth century. Archipel 45: 77-96. https://doi.org/ 10.3406/arch.1993.2894 
Lansing, J.S. 1974. Evil in the morning of the world: Phenomenological approaches to a Balinese community. Ann Arbor: University of Michigan, Center for South and Southeast Asian Studies.

1991. Priests and programmers: Technologies of power in the engineered landscape of Bali. Princeton: Princeton University Press.

Lewis, M.W. 1999. Dividing the ocean sea. The Geographical Review 89(2): 188-214. https://doi.org/10.2307/216086

Li, T. 1998. Nguyen Cochinchina: Southern Vietnam in the seventeenth and eighteenth centuries. Ithaca: Cornell Southeast Asia Program.

2006a. The rise and fall of the Jiaozhi ocean region. In The perception of maritime space in traditional Chinese sources, eds. A. Schottenhammer and R. Ptak, 125-139. Wiesbaden: Harrassowitz Verlag. 2006b. The eighteenth-century Mekong delta and its world of water frontier. In Viet Nam borderless histories, eds. Nhung Tuyet Tran and A. Reid, 147-162. Madison: University of Wisconsin Press.

2016. A historical sketch of the landscape of the Red River delta. TRaNS (Trans-Regional and National Studies of Southeast Asia) 4(2): 351-363. https://doi. org/10.1017/trn.2016.8

Lowe, C. 2003. The magic of space: Sama at sea and on land in Sulawesi, Indonesia. Bijdragen tot de Taal-, Land- en Volkenkunde 159(1): 109-133. https://doi. org/10.1163/22134379-90003753

Malo, D. 1971 (1951). Hawaiian antiquities (2nd ed.) (Trans. by N. B. Emerson). Honolulu: Bishop Museum Press.

Mayoury and Nagaosrivathana, P. 2007. The enduring sacred landscape of the Naga. Chiengmai: Mekong Press.

Mosse, D. 2011. The rule of water: Uncertainty and the cultural ecology of water in South India. In A history of water, series II, vol. 1: Idea of water from ancient societies to the modern world, eds. T. Tvedt and T. Oestigaard, 218-230. London: I.B. Tauris.

Oestigaard, T. 2005. Death and life-giving waters: Cremation, caste, and cosmogony in karmic traditions. British Archaeological Reports (BAR) International Series 1353. Oxford: Archaeopress.

Paredes, O. 2016. Rivers of memory and oceans of difference in the Lumad world of Mindanao. TRaNS (Trans-Regional and National Studies of Southeast Asia) 4(2): 329-349. https://doi.org/10.1017/trn.2015.28

Pearson, M.N. 1985. Littoral society: The case for the coast. The Great Circle: Journal of the Australian Association for Maritime History 7(1): 1-8.

2003. The Indian Ocean. London and New York: Routledge. https://doi. org/10.4324/9780203414132

2006. Littoral society: The concept and the problems. Journal of World History 17(4): 353-373. https://doi.org/10.1353/jwh.2006.0059

Penny, D. 2010. The Mekong River system and the end of the Angkor civilization: A water historical perspective. In A history of water, series II, vol. 2; Rivers and society: From early civilizations to modern times, eds. T. Tvedt and R. Coopey, 129-143. London and New York: I.B. Tauris. 
Pham, D. 2015. Power, ecstasy, and enlightenment: The role of the Bale Kambang in 17th century Balinese kingship. MA dissertation, University of Hawai' $i$.

Pringle, R. 1970. Rajahs and rebels: The Ibans of Sarawak under Brooke rule, 1841-1941. Ithaca: Cornell University Press.

Sbeghen, J.A.M. 2004. An analysis of the sculpture of Candi Sukuh in Central Java: Its meanings and religious functions 1437-1443 C.E. PhD dissertation, University of Queensland.

Stark, M. and Acabado, S. 2014. Sacred and social water management in pre-modern Southeast Asia: Lowland Khmers and upland Cordillerans. Paper presented at Conference on Water, Sogang University, Seoul, 26-27 June.

Steinberg, P.E. 2003. The social construction of the ocean. New York: Cambridge University Press.

Taylor, P. 2014. Water in the shaping and unmaking of Khmer identity on the VietnamCambodia frontier. TRaNS (Trans-Regional and National Studies of Southeast Asia) 2(1): 103-130. https://doi.org/10.1017/trn.2013.18

Tvedt, T. 2010a. Water systems, environmental history and the deconstruction of nature. Environment and History 16(2): 143-166. https://doi.org/10.3197/09673401 0X12699419057179

2010b. Why England and not China and India? Water systems and the history of the Industrial Revolution. Journal of Global History 5(1): 29-50. https://doi. org/10.1017/S1740022809990325

Vannote R.L., Minshall, G.W., Cummins, K.W., Sedell, J.R. and Cushing, C.E. 1980. The river continuum concept. Canadian Journal of Fisheries and Aquatic Sciences 37(1): 130-137. https://doi.org/10.1139/f80-017

Water Resource Research Center. 2006. Looking to Hawaii's past to insure a sustainable future: Significance of water in Hawaiian culture. Power Point presentation. http://www.wrrc.hawaii.edu/seminars/Wai-6perpage.pdf (accessed 3 October 2018).

Wheeler, C. 2006. Re-thinking the sea in Vietnamese history: Littoral society in the integration of Thuan-Quang, seventeenth-eighteenth centuries. Journal of Southeast Asian Studies 37(1): 123-153. https://doi.org/10.1017/S0022463405000445 